\title{
Computation of Groundwater Draft for Handri River Basin in Andhra Pradesh, India
}

\author{
${ }^{1}$ D Gouse Peera, ${ }^{\text {*2}}$ R. Bhavani \\ ${ }^{1}$ Department of Civil Engineering, AITS Rajampet, Andhra Pradesh, India \\ ${ }^{2}$ JNTUA, Anannthapuramu, Andhra Pradesh, India \\ Email: 'gouse_mgr@yahoo.in, ${ }^{2}$ rbhavani77@yahoo.com
}

Received: 20th November 2019, Accepted: 04th December 2019, Published: 31st December 2019

\begin{abstract}
In India assessment of groundwater is based on guidelines of Groundwater Estimation Committee which is formed by government of India. Groundwater assessment involves groundwater draft. For computation of groundwater draft various data is required. Data includes area, canal particulars, well particulars, depth to water level bgl (m), water bodies, area irrigated under groundwater under surface water, recharge. For computation of groundwater draft Groundwater Estimation Committee methodology is used in the present study. The study area considered for assessment of groundwater resources is Handri river basin, a tributary of Tungabadra river in Kurnool district of Andhra Pradesh. In this paper draft is computed for monsoon and nonmosoon seasons and considered commanded area only. draft computed for watersheds which are fall in river basin for commanded area only. Different mathematical models are used for computation of draft. Data is collected from various departments namely Central Ground Water Board, Agriculture department, Panchayat raj Department.
\end{abstract}

\section{Keywords}

Groundwater, Assessment, Recharge, Draft, River

\section{Introduction}

Present methodology is based on recommendations of Groundwater Estimation Committee which is formed by government of India. In the present study only gross groundwater draft is estimated. For computation of gross groundwater draft various data is required. Data includes village data, canal particulars, well particulars, depth to water level bgl (m), water bodies, area irrigated with groundwater and surface water, recharge. Gross groundwater draft is computed for various factors such as gross groundwater draft for irrigation, annual gross groundwater draft for irrigation, annual gross groundwater draft for all uses, gross groundwater draft for all uses during monsoon season, current annual gross groundwater draft for irrigation per unit area, current annual gross groundwater draft for all uses per unit area. [5] This groundwater draft is used for recharge calculations by different methods such as Water Table Fluctuation Method and Rainfall Infiltration Factor method which is recommended by Groundwater Estimation Committee. This groundwater draft may be computed for command area, non-command area and poor groundwater quality area for both monsoon season and non-monsoon season. [6]

\section{Study Area}

The study area considered for computation of groundwater draft is Handri river basin, a tributary of Tungabadra river in India (Fig. 1). The origin is between Pattikonda and Aspari and mingle in river Tungabhadra which is one of the major tributary of river Krishna. In this paper only commanded area of 4 watersheds are considered.

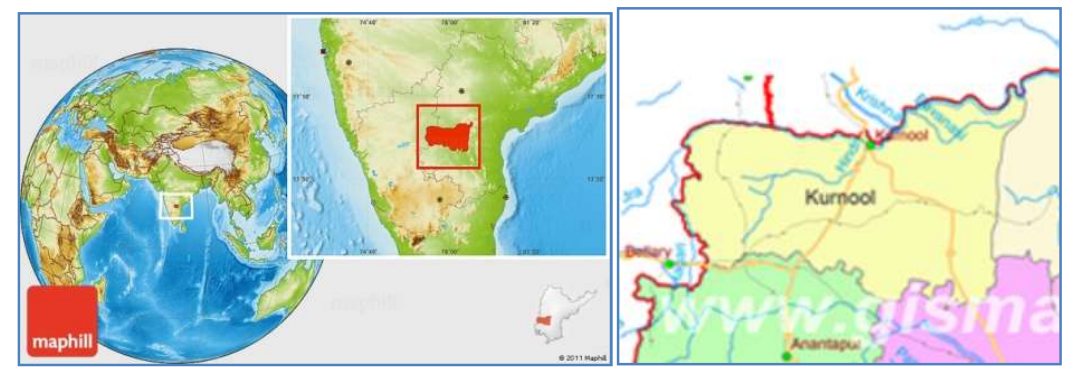

Fig. 1: Study Area Map

\section{Data Used}

Village data which contains general details such as area, forest area, hilly area and population for command and noncommand areas, groundwater quality, water-logged and shallow water table area and average deep tube wells in the area (should be less than $5 \mathrm{~m}$ ), flood prone area and number of days in a year which water retained in flood prone area. 
Canal particulars such as length, design depth of flow, bed width, side slopes, wetted perimeter, number of operating days of canal, seepage factor, wetted area, recharge from canal, annual recharge.

Particulars of different types of wells such as dug well, dug well with pump set, bore well, shallow tube well, medium tube well, deep tube well for arriving at groundwater draft in the basin and the draft in each village (local draft). Growth rate of bore wells in percent per annum based on average of applications received for energisation and actual energized (APTRANSCO) for command and non-command and poor quality areas. Growth rate of dug wells in percent per annum based on random inventory of wells in $1 \%$ of the villages for command and non-command and poor quality areas. Data required also for depth to water level bgl $(\mathrm{m})$ for pre-monsoon and post-monsoon for command and non-command and poor quality areas, estimated draft per well/day [cum/day], days of operation of wells for monsoon and non-monsoon, dependence on groundwater for domestic and industrial needs (as fraction 1= $100 \%$ dependence) in command area and non-command area.

Water bodies such as minor irrigation tanks, artificial recharge structures for monsoon and non-monsoon.[2] Data taken for area irrigated for paddy and non-paddy for kharif and rabi and also for command and non-command and poor quality areas for monsoon and non- monsoon.

\section{Methodology}

Gross groundwater draft is computed for gross groundwater draft for irrigation, annual gross groundwater draft for irrigation, annual gross groundwater draft for all uses, gross groundwater draft for all uses during monsoon season, current annual gross groundwater draft for irrigation per unit area, current annual gross groundwater draft for all uses per unit area.

The following equations are used for draft calculations.

Gross groundwater draft for irrigation $=$ Estimated no of wells $*$ Estimated gross ground water draft $/$ well

Estimated no of wells $=$ No of wells $*\left\{\frac{100+A}{100}\right\}^{B}$

$\mathrm{A}=$ Growth rate of wells in \% per annum based on average of applications received for energisation and actual energised [APTRANSCO]

$\mathrm{B}=$ Year of assessment - Year of number of irrigation wells

Estimated gross ground water draft /well

$$
=\frac{\text { Estimated draft per well/day }[\mathrm{cum} / \text { day }] * \text { Days of operation of wells for non }- \text { Monsoon }}{10000}
$$

Annual gross groundwater draft for irrigation

$=$ Gross groundwater draft for Irrigation during monsoon season

+ Gross groundwater draft for Irrigation during non - monsoon season

Annual gross groundwater draft for all uses

$=$ Annual gross groundwater draft for irrigation

+ Annual gross groundwater draft for domestic water supply

+ Annual gross groundwater draft for industrial water supply

Gross groundwater draft for all uses during monsoon season $=$ Gross groundwater draft for irrigation + Gross groundwater draft for domestic water supply + Gross groundwater draft for industrial water supply 
Current annual gross groundwater draft for irrigation per unit area $=\left\{\frac{C}{D}\right\} * 1000$

$\mathrm{C}=$ Gross groundwater draft for Irrigation during monsoon season

+ Gross groundwater draft for Irrigation during non - Monsoon season

$\mathrm{D}=$ Area covered in water shed - Area covered in hilly area

Current annual gross groundwater draft for all uses per unit area $=\left\{\frac{E}{F}\right\} * 1000$

$\mathrm{E}=$ Annual gross groundwater draft for irrigation

+ Annual gross groundwater draft for domestic water supply

+ Annual gross groundwater draft for industrial water supply

$\mathrm{F}=$ Area covered in water shed - Area covered in hilly area

\section{Results and Discussions}

Groundwater draft values are estimated for Handri river basin in Andhra Pradesh. In the present study only command area is studied. [12] Four Watersheds are fall under command area namely Adoni, Devanakonda, Kalluru and Kodumur. The ground water draft values are shown in Fig.2, Fig.3, Fig.4 and Fig.5. The ground water draft values are estimated using equations (1) to (14). From the calculations Kodumur Watershed shows highest value of 810 Ha-m and Kalluru Watershed shows lowest value of 10 Ha-m.

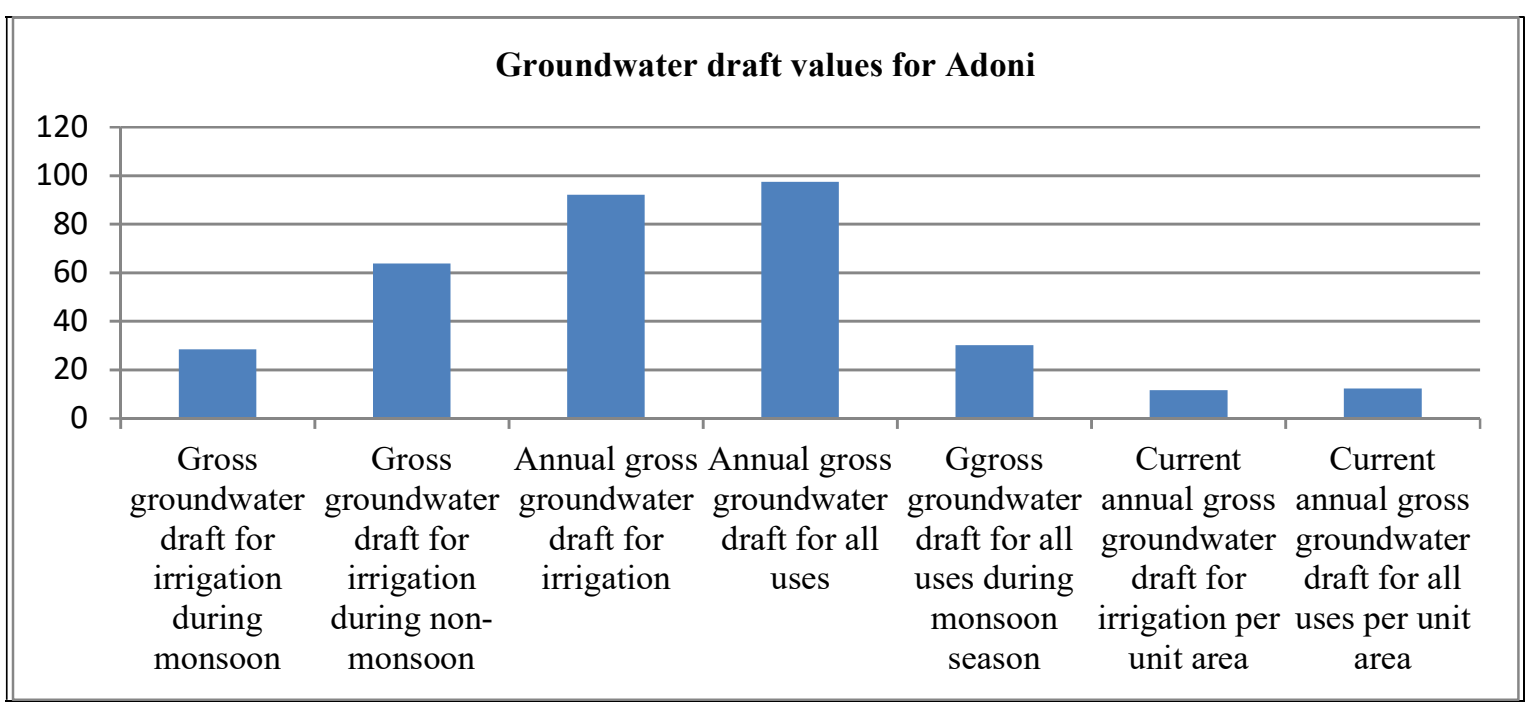

Fig. 2: Groundwater Draft Values for Adoni Watershed. 


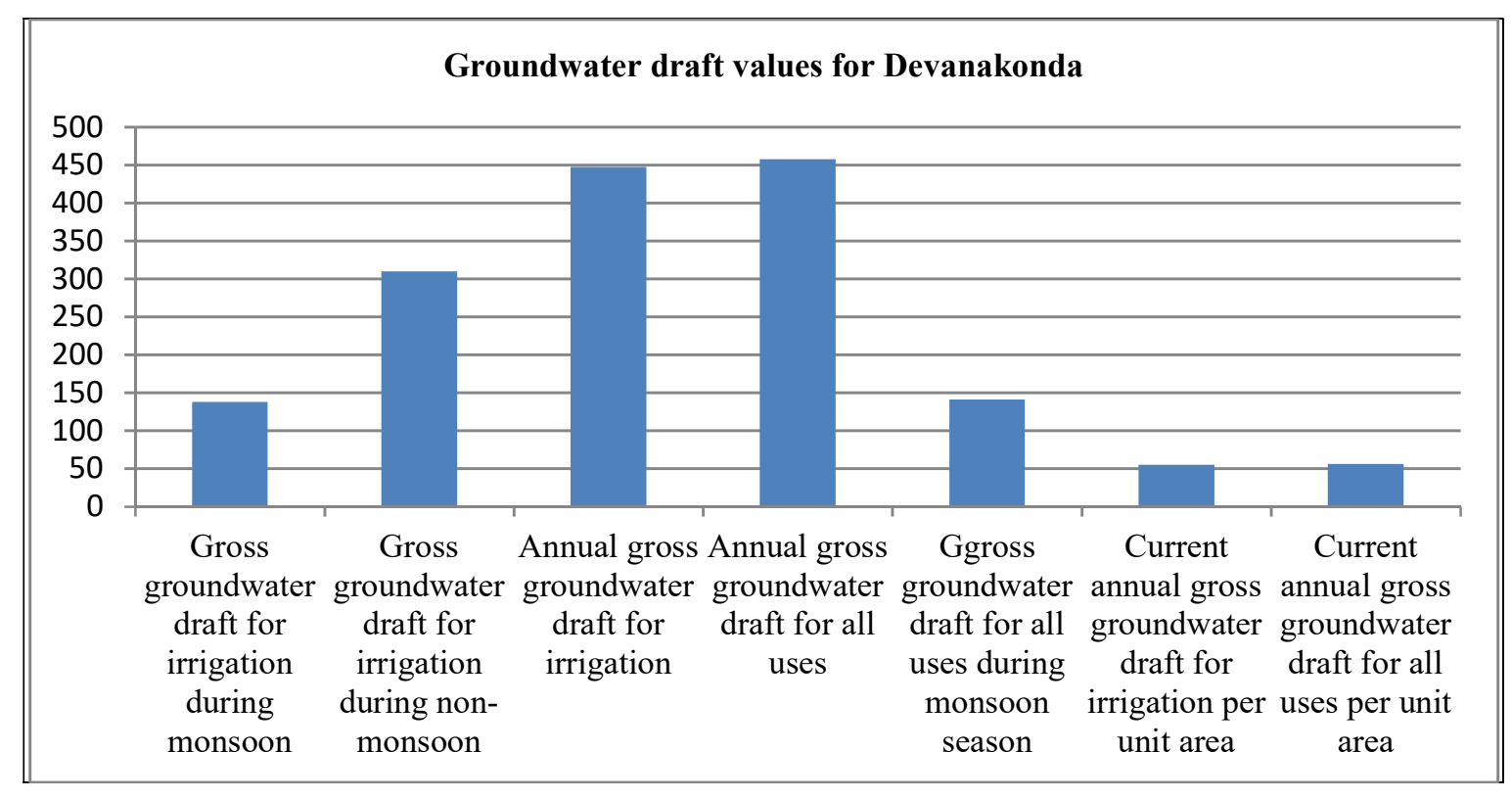

Fig. 3: Groundwater Draft Values for Devanakonda Watershed.

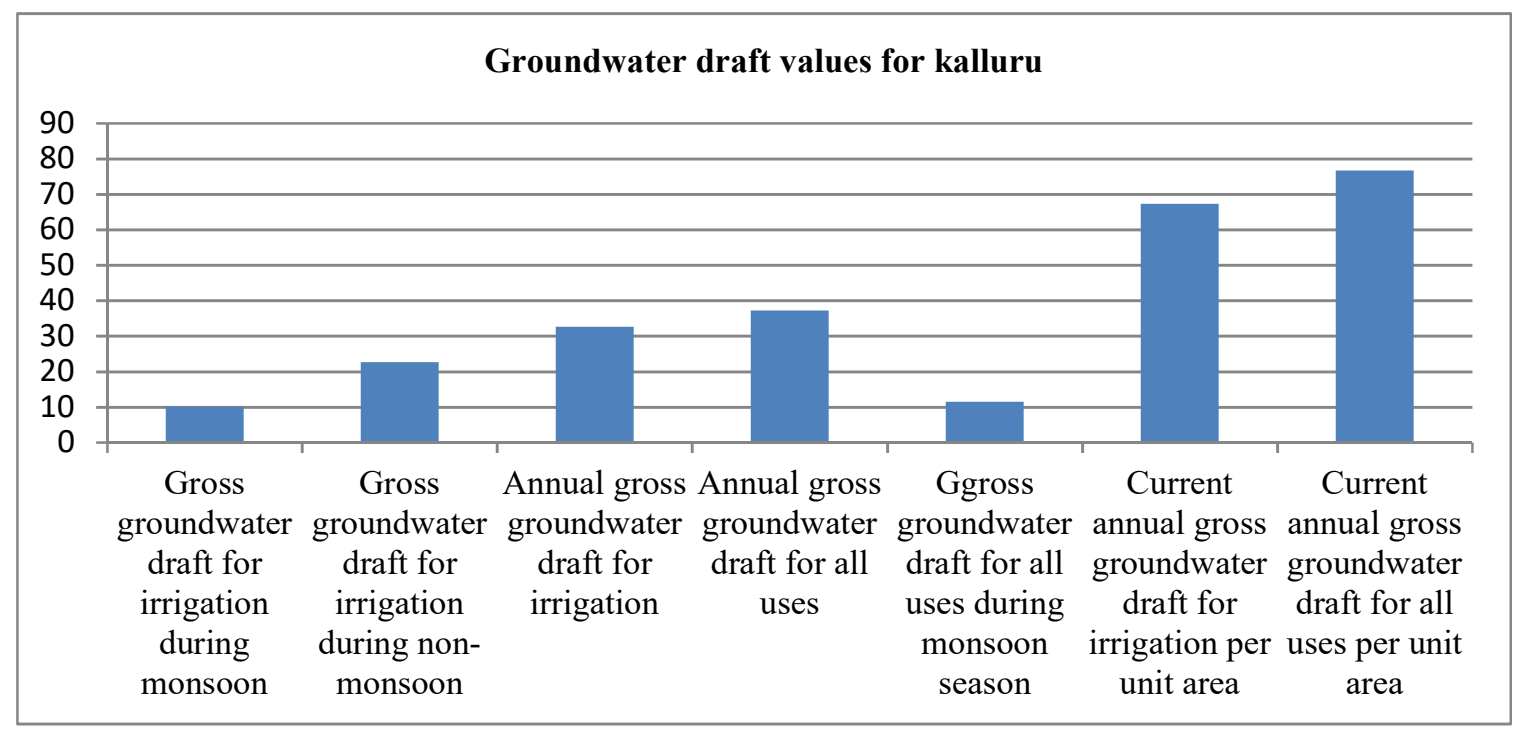

Fig. 4: Groundwater Draft Values for Kalluru Watershed. 


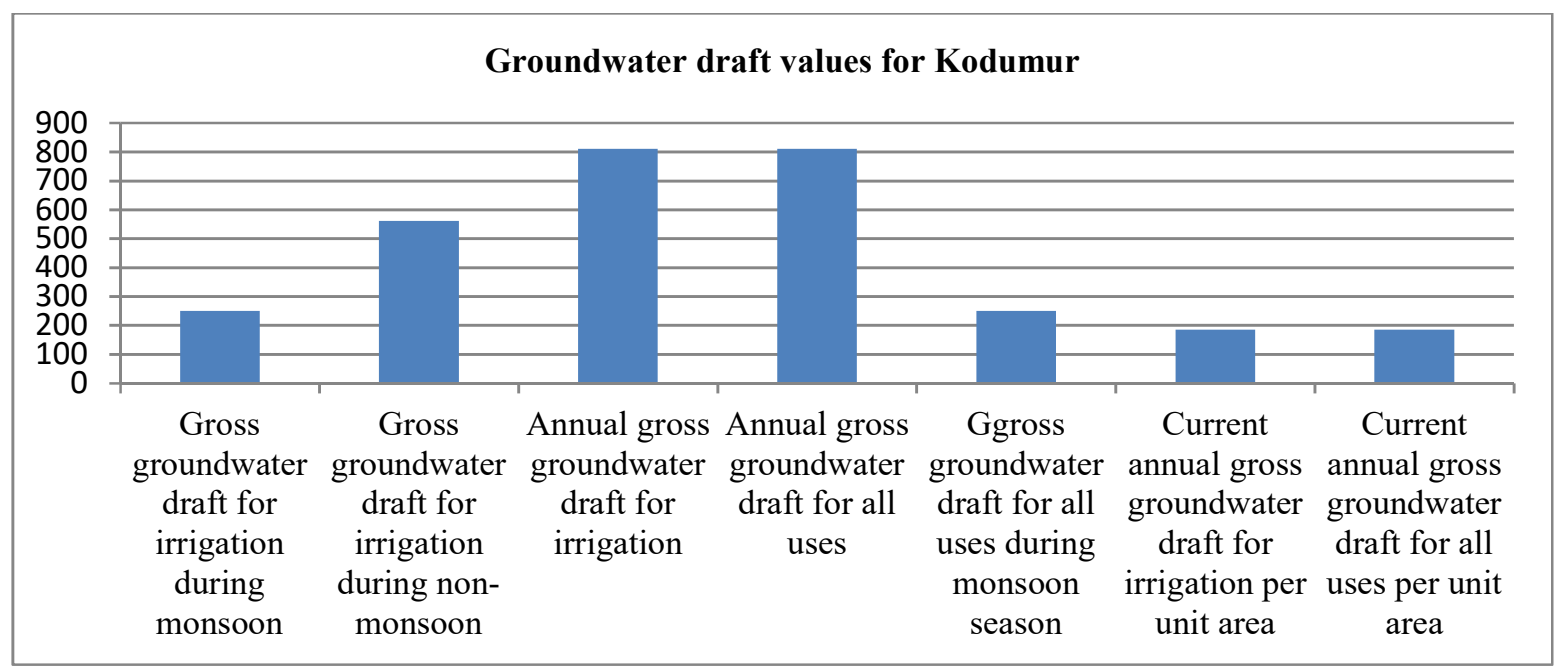

Fig. 5: Groundwater Draft Values for Kodumur Watershed.

\section{Conclusions}

Groundwater draft computations are carried out based on recommendations of Groundwater Estimation Committee (GEC). But groundwater draft values are estimated for command area only. These values are helpful in assessment of groundwater. [11] Present study carried out for limited available data.

\section{Acknowledgements}

The author would thankful to Central Ground Water Board, Kurnool for support to this research.

\section{References}

[1]. Bhavani R, "Computation of yield based on weighted normal monsoon rainfall for Kundu sub-basin of Pennar basin", International Journal of Advanced Scientific and Technical Research, Issue 5 Volume 7 (2015), ISSN 22499954, p 25-31.

[2]. Central Ground Water Board (1987), "Hydrogeology and groundwater balance of the Vedavathi river basin in parts of Karnataka and Andhra Pradesh, An interim report (1987)

[3]. Central Ground Water Board(1987), "Water balance studies in upper Yamuna basin, Terminal report (2000)

[4]. Chavent G, "Local stability of the output least square parameter estimation technique", Math. Appli. Comp., (1983), Vol 2, p 3-22.

[5]. Ground water resource estimation methodology, Report of the ground water resource estimation Committee, Ministry of water resources, Government of India (2009)

[6]. Karanth K. R., "Groundwater assessment development and management, Tata McGraw Hill publishing Co. Ltd, (1994).

[7]. NagarajM.K. (1999)., "Parameter estimation of regional ground water system"., Ph.D thesis., IIsc., Bangalore.

[8]. National conference on emerging trends in the development of sustainable groundwater resources (1997), JNTU, Hyderabad p.361

[9]. Nowel Njamnsi Y, "Estimation for groundwater balance based on recharge and discharge: a tool for sustainable groundwater management, Zhongmu county alluvial plain aquifer, Henna province, China" Journal of American science, (2009) p 83-90

[10]. Okkebatelaan and Florimond De Smedt, "WetSpass: a flexible, GIS based, distributed recharge methodology for regional groundwater modeling", Impact of Human Activity on Groundwater Dynamics (2001). IAHS Publ. no. 269, p 11-17

[11]. Raghunath H.M., "Groundwater”, Willy Eastern Ltd, (1992) p.563

[12]. RanaChatterjee, Groundwater resource estimation , Journal GEOL.SOC, Vol 77 (2011) 